\title{
Sequential electrodialytic recovery of phosphorus from low-temperature gasification ashes of chemically precipitated sewage sludge
}

Parés Viader, Raimon; Jensen, Pernille Erland; Ottosen, Lisbeth M.; Ahrenfeldt, Jesper; HauggaardNielsen, Henrik

Published in:

Waste Management

Link to article, DOI:

10.1016/j.wasman.2016.11.030

Publication date:

2017

Document Version

Peer reviewed version

Link back to DTU Orbit

Citation $(A P A)$ :

Parés Viader, R., Jensen, P. E., Ottosen, L. M., Ahrenfeldt, J., \& Hauggaard-Nielsen, H. (2017). Sequential electrodialytic recovery of phosphorus from low-temperature gasification ashes of chemically precipitated sewage sludge. Waste Management, 60, 211-218. https://doi.org/10.1016/j.wasman.2016.11.030

\section{General rights}

Copyright and moral rights for the publications made accessible in the public portal are retained by the authors and/or other copyright owners and it is a condition of accessing publications that users recognise and abide by the legal requirements associated with these rights.

- Users may download and print one copy of any publication from the public portal for the purpose of private study or research.

- You may not further distribute the material or use it for any profit-making activity or commercial gain

- You may freely distribute the URL identifying the publication in the public portal 
Sequential electrodialytic recovery of phosphorus from low-temperature gasification ashes of

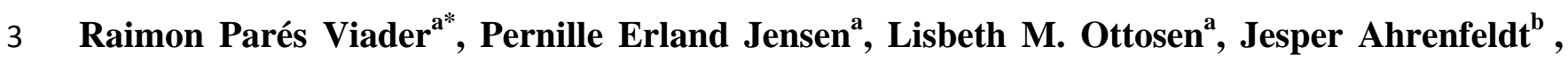

4 Henrik Hauggaard-Nielsen ${ }^{\mathrm{c}}$

${ }^{a}$ Department of Civil Engineering, Technical University of Denmark, Building 118, 2800 Kongens

Lyngby, Denmark

${ }^{b}$ Department of Chemical and Biochemical Engineering, Building 313, Technical University of

Denmark, 4000 Roskilde, Denmark

9

${ }^{c}$ Department of Environmental, People and Technology, Roskilde University, 4000 Roskilde,

Denmark

*Corresponding author: rapv@byg.dtu.dk, Tel: +4545252163

\section{Abstract}

Phosphorus recycling from secondary materials like sewage sludge ashes offers an alternative to mining of phosphates from primary resources and a mean to counteract the current phosphorous rock depletion concern. A separation of $\mathrm{P}$ from the bulk ash is normally required, due to its low plant availability and the presence of heavy metals. Previously, more than $80 \%$ of $\mathrm{P}$ was recovered from incineration sewage sludge ashes using a two-compartment electrodialytic cell. In contrast, the recovery was below $30 \%$ for ashes from low-temperature gasification using the same setup. The low recovery was due to a high presence of Al- and Fe(III)-P bindings. In the present study, an

21 electrodialytic process combining sequentially a pair of two-compartment cells allowed a recovery of up to $70 \%$ of phosphorus from these ashes. The use of a second cell, where the ash was 
23 suspended in an alkaline solution, allowed the P solubilisation from aluminium and ferric

24 phosphates. In addition, $\mathrm{P}$ was separated from most metals as they became insoluble under the 25 prevailing chemical environment. The obtained ratio of $\mathrm{Al}, \mathrm{Fe}, \mathrm{Mg}$ and most heavy metals to $\mathrm{P}$ was

26 comparable to wet process phosphoric acid. Therefore, this sequential process was found to be

27 suitable to recycle $\mathrm{P}$ and potentially use it in the production of common fertilizers like diammonium 28 phosphate.

30 Keywords: Electrodialysis, Heavy metals, Iron phosphates, Low-temperature gasification,

31 Phosphorus, Sewage sludge ash 


\section{Introduction}

Europe is dependent on phosphate rock imports [1], the reserves of which are estimated to be exhausted within 50-400 years [1-3]. The European Commission included this mineral in the list of 20 critical raw materials in 2014. Moreover, mineral P-fertilizers are the main contributors of toxic elements accumulation such as cadmium [4] and uranium [5] in agricultural soils. For these reasons, P recycling from secondary resources, like sewage sludge, has gained increased attention among researchers, private companies and public institutions over the last decade [6-9]. Around 16\% of phosphate rock import can be potentially substituted with unrecycled P from sewage sludge in Europe [1]. In order to promote P recycling, some countries e.g. Denmark have set goals for P recovery [10], and others e.g. Germany, Switzerland and Sweden currently have proposals to make it obligatory. The content of heavy metals as well as potential unwanted organic pollutants and pathogens are of major concerns in respect to sewage sludge's direct use on agricultural fields [8,

11]. Another difficulty is the limited plant-availability of $P$ when sewage sludge is precipitated with $\mathrm{Al}$ and Fe salts in the wastewater treatment plant to avoid eutrophication of natural water system recipients, a practice which is common in many countries [7, 12-15].

Thermal processes such as incineration [16] and low-temperature gasification [17] can lead to the removal of organic contaminants from sewage sludge, but additional treatments of the resulting sewage sludge ashes (SSA) are required to separate P from heavy metals and ensure its bioavailability $[7,8,18,19]$. Electrodialysis (ED) has been studied as a technique to extract P from different SSA using 2-compartment cells [19, 20]. In this setup, SSA is suspended in water in the anode compartment, which is separated from the cathode compartment by a cation exchange membrane. When applying the electric field the cations are transported from the anolyte to the catholyte through the membrane. Protons are concurrently produced from water electrolysis at the anode, which increases the solubilisation of the different elements present in the SSA [19, 20]. Thus, 
the applied electric field results in acidic leaching combined with cation migration into the cathode compartment. Large recoveries of P (higher than 80\%) have been achieved for incineration SSA [20] and biologically precipitated SSA from low-temperature gasification [19].On the contrary, less than $26 \%$ of P was recovered from chemically precipitated SSA from the same gasification unit. The reason for the low recovery was found to be the influence of Fe(III) on P-solubility and the formation of positively charged Fe-P complexes in acidic medium [19].

Other processes than ED has been investigation for the recovyer of P from SSA and the majority can be grouped into either:

a) Acid extraction of $\mathrm{P}$ from SSA with $\mathrm{H}_{2} \mathrm{SO}_{4}, \mathrm{HCl}, \mathrm{HNO}_{3}$ and/or $\mathrm{H}_{3} \mathrm{PO}_{4}$, followed by further steps to separate $\mathrm{P}$ from the leached impurities like heavy metals by means of sulphide precipitation [18], solvent extraction [21] and/or ion exchange columns [13, 18, 22, 23], as well as through the chemical precipitation of $\mathrm{P}$ as Ca-phosphates [9, 22, 24, 25]. The biggest industrial agreement to recycle P from SSA until now was signed in the beginning of 2015 between the Belgian company Ecophos and the Dutch companies HVC and SNB, which includes the construction of a plant to treat 50-60,000 tonnes of incineration SSA yearly using a method belonging to this group.

b) Thermal removal of heavy metals at high temperatures (above $1400^{\circ} \mathrm{C}$ ) $[9,26]$, which also allows the separation of the main metals like Fe; or at around $1000^{\circ} \mathrm{C}$ in combination with chemicals like calcium or magnesium chloride [27], Na- and K- salts and bases [9, 28, 29], which at the same time increases the plant availability of $\mathrm{P}$ in the ashes.

However, these researches have focused on chemically precipitated incineration SSA, where Fe(III) is not controlling P solubility [30, 31], which is on the contrary to gasification SSA. An alkaline extraction step could potentially dissolve Fe(III)-phosphates [32, 33] existing in gasification SSA, 
with the advantage of preventing the formation of complexes like $\mathrm{Fe}\left(\mathrm{H}_{2} \mathrm{PO}_{4}\right)^{2+}$ or $\mathrm{Fe}\left(\mathrm{HPO}_{4}\right)^{+}$which complicate P separation in ion exchange processes and ED [19, 34]. By such treatment, alkalineinsoluble Ca-phosphates [35] would, however, not be dissolved. Instead, a common strategy to leach $\mathrm{P}$ from materials containing both $\mathrm{Ca}-\mathrm{P}$ and $\mathrm{Al} / \mathrm{Fe}(\mathrm{III})-\mathrm{P}$ bonds, previously used for $\mathrm{Al}-$ precipitated SSA [36, 37], soils [38], sediments [39], and municipal solid waste fly ashes [40], is to solubilize the different Ca-bearing phases in an acidic step, and the $\mathrm{Al} / \mathrm{Fe}(\mathrm{III})-\mathrm{P}$ bindings in an alkaline step. Nevertheless, the order of execution requires an investigation. Starting with an acidic extraction can lead to P re-precipitation as Al-P [36, 37], and probably Fe(III)-P, which increases the hydroxide demand for their dissolution in the subsequent alkaline step. Starting with an alkaline extraction, P could re-precipitate as Ca-P or adsorb to Ca compounds [37, 38, 41], which increases the proton demand for P dissolution in the following acidic step. In order to assess which combination is best to recover $\mathrm{P}$, both possible two-stage chemical processes are compared in the present study.

Recently, a patent concerning an innovative sequential ED process (Fig. 1) has been filed with the European Patent application number 15187370.0. The new method combines two existing 2compartment cell configurations, one with a cation exchange membrane $[19,20]$ and another one with an anion exchange membrane [42], into a sequential process. The present research focuses on achieving a higher recovery of P from low-temperature gasification SSA, which has been chemically precipitated, using a sequential ED process in comparison to a single step with a 2compartment cell with a cation exchange membrane. 


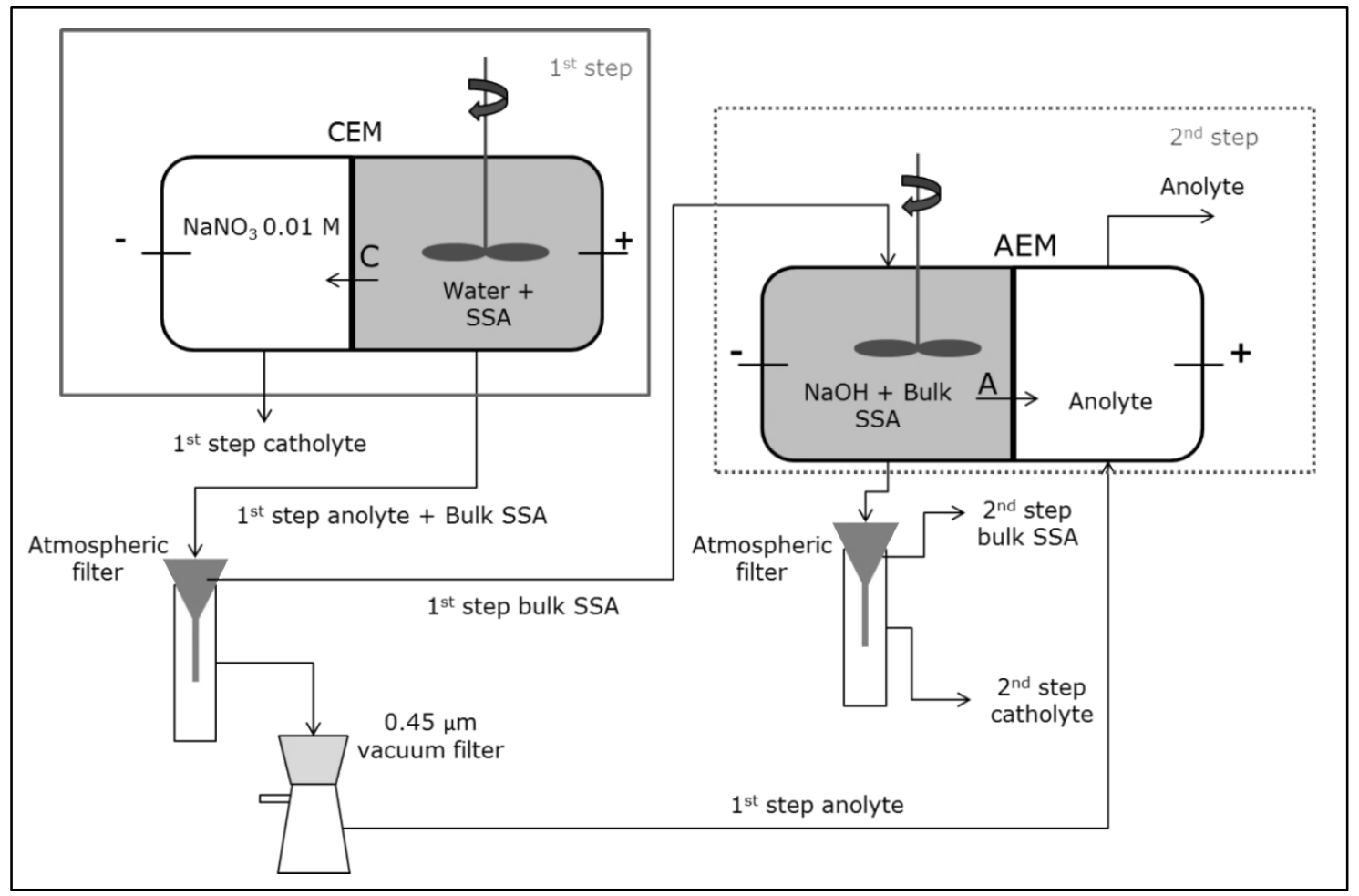

Fig. 1. Schematic view of the sequential ED process. C: cations, A: anions. 


\section{Experimental}

\subsection{Experimental SSA}

The investigated SSA were the same as in previous published work [19], where the ashes were collected from the second cyclone of a $100 \mathrm{~kW}$ experimental Low Temperature Circulating Fluid Bed gasifier [43] at the Department of Chemical and Biochemical Engineering in the Technical University of Denmark. The original feedstock was dried sludge collected at the wastewater treatment plant in the Randers Municipality, Denmark, where P was captured approximately 50:50 by biological and chemical means. The chemical precipitation was based on Fe and Al chlorides.

\subsection{Analytical methods and sampling}

Small batches of around 200 grams were sampled from the total mass collected. Each batch was dried at $105^{\circ} \mathrm{C}$ overnight, cooled in the fume hood, homogenised with a steel spatula and immediately stored in plastic bags under dry conditions. A different batch was used for each experiment: alkaline extraction (Batch 1), two-stage chemical extraction (Batch 2) and ED experiments (Batch 3). The $\mathrm{CaCO}_{3}$ content in another separate batch from the same overall sample was measured following the German standard DIN 18129 [44].

The concentrations of elements were measured for each batch: in triplicates for the alkaline extraction as well as for the sequential extraction, and in eight samples for the ED experiments. It was also measured in triplicates after each step of the sequential extraction and the ED experiments. The targeted elements were: Al, As, Ca, Cd, Cu, Cr, Fe, K, Mg, Ni, P, Pb and Zn. Na was analysed only for the initial samples of the ED experiments. Their content was measured by Varian 720-ES inductively coupled plasma optical emission spectrometry (ICP-OES) after pre-treatment by Danish Standard DS259 [45]: $1 \mathrm{~g}$ ash and 20mL $7.3 \mathrm{M} \mathrm{HNO}_{3}$ were heated at $200 \mathrm{kPa}\left(120^{\circ} \mathrm{C}\right)$ for $30 \mathrm{~min}$. 
The liquid was thereafter separated by vacuum filtration through a $0.45 \mu \mathrm{m}$ filter and diluted to 100 mL with deionised (DI) water.

Element concentrations among the batches were compared through a one-way analysis of variances (ANOVA).

\subsection{Alkaline extraction}

In order to assess the dependence of solubility of the target elements to alkaline solutions, $5 \mathrm{~g}$ of ash was shaken at $150 \mathrm{rpm}$ for 1 week with $25 \mathrm{~mL}$ of $\mathrm{NaOH}$ at $1,0.5,0.1,0.05$ and $0.01 \mathrm{M}$ respectively. The $\mathrm{pH}$ of the leachate was measured by a Radiometer Analytical $\mathrm{pH}$ electrode. The concentrations of the targeted elements in the leachate were measured by the Varian 720-ES ICPOES after filtration through a $0.45 \mu \mathrm{m}$ syringe filter.

\subsection{Two-stage chemical extractions}

Two different two-stage chemical extraction procedures were compared in order to investigate the most suitable order of the sequential P-extraction: alkaline-acid or acid-alkaline. The combined acid and base load $\left(\mathrm{H}^{+}\right.$and $\mathrm{OH}^{-}$moles per $\mathrm{kg}$ of dry ash) was equal to 5; this value was equivalent to the acid load in which almost all P could be mobilised in a previous research with the same ash [19]. In the alkaline-acid extraction, $10 \mathrm{~g}$ of ash were shaken at $150 \mathrm{rpm}$ for 24 hours with $50 \mathrm{~mL}$ of $\mathrm{NaOH}$ at $0.5 \mathrm{M}$; the ash suspension was filtered at atmospheric pressure, the filtrate volume and $\mathrm{pH}$ were measured and sampled with a $0.45 \mu \mathrm{m}$ syringe filter, and the ash was dried during 48 hours at $50{ }^{\circ} \mathrm{C}$. The dried ash was weighted, loosened by hand in a mortar, sampled and $5 \mathrm{~g}$ of it were shaken at 150 rpm for 24 hours with $25 \mathrm{~mL}$ of $\mathrm{HNO}_{3}$ at $0.5 \mathrm{M}$. In the acid-alkaline extraction, the same procedure was repeated starting with a step with $0.5 \mathrm{M} \mathrm{HNO}_{3}$ followed by $0.5 \mathrm{M} \mathrm{NaOH}$. All targeted elements were measured by the Varian 720-ES ICP-OES in the liquid phases at the end of each step. The 

overall \% of P extraction was calculated as:

$$
\begin{aligned}
& \% P \text { extraction }=\frac{P \text { extracted in filtrates }}{\text { Total } P \text { at the end of the experiment }} \\
& =\frac{V_{\text {acid }} \cdot C_{P-\text { acid }}+V_{\text {alkaline }} \cdot C_{P-\text { alkaline }} \cdot \frac{m_{\text {ash-acid }}}{m_{\text {ash-start }}}}{V_{\text {acid }} \cdot C_{P-\text { acid }}+\left(V_{\text {alkaline }} \cdot C_{P-\text { alkaline }}+C_{P-\text { ash-alkaline }} \cdot m_{\text {ash-alkaline }}\right) \cdot \frac{m_{\text {ash-acid }}}{m_{\text {ash-start }}}}
\end{aligned}
$$

151 Where $\mathrm{V}_{\text {acid }}$ and $\mathrm{V}_{\text {alkaline }}$ were the volumes of filtrates recovered after each extraction, $\mathrm{C}_{\mathrm{P} \text {-acid }}$ and $\mathrm{C}_{\mathrm{P} \text { - }}$

152 alkaline the concentration of $\mathrm{P}$ in these filtrates, $\mathrm{C}_{\mathrm{P} \text {-ash-alkaline }}$ the $\mathrm{P}$-concentration in the dry ash after the

153 alkaline extraction, whereas $\mathrm{m}_{\text {ash-start }}, \mathrm{m}_{\text {ash-acid }}$ and $\mathrm{m}_{\text {ash-alkaline }}$ were the mass of dry ash at the

154 beginning and at the end of each extraction. The reason for the inclusion of the ratio between $\mathrm{m}_{\text {ash- }}$

155 acid and $\mathrm{m}_{\text {ash-start }}$, multiplying the second term in the dividend and the divisor, was to extrapolate the result of the alkaline extraction step to all the bulk dry ash mass after the acid extraction. The same equation was used to calculate $\mathrm{Ca}, \mathrm{Al}$ and Fe extraction.

\subsection{ED experimental setup}

An illustration of the ED sequential process used is shown in Fig. 1. Both cells consisted of two compartments made of cylindrical Plexiglas ${ }^{\circledR}$ with an internal diameter of $8 \mathrm{~cm}$. The compartment with the ash suspension was $10 \mathrm{~cm}$ long and the other compartment $5 \mathrm{~cm}$. The anode compartment contained $35 \mathrm{~g}$ ash and $350 \mathrm{ml}$ DI water. In the second step, the cathode compartment contained 25 $\mathrm{g}$ of the bulk ash resulting from the first step and $300 \mathrm{ml}$ DI water, as well as $8 \mathrm{~mL}$ of $\mathrm{NaOH} 1 \mathrm{M}$ added at the beginning of the experiment. A plastic strip attached to a glass-stick connected to an overhead stirrer (IKA RW11) was used to stir the ash suspensions during the experiments. In the cathode compartment of the first step, $500 \mathrm{~mL}$ electrolyte solution $\left(0.01 \mathrm{M} \mathrm{NaNO}_{3}\right.$, $\mathrm{pH}<2$ adjusted with $\mathrm{HNO}_{3}$ ) was circulated by a Plastomec pump model P05. In the anode compartment of the 
second step, the anolyte resulting from the first step was circulated using the same pump model after vacuum filtration through a $0.45 \mu \mathrm{m}$ filter. The electrodes were made of platinum coated titanium wire (diameter 3 mm) obtained from Permascand®. An Agilent E3612A DC power supply was used to maintain a constant DC current. The cation and anion exchange membranes used were from Ionics (model CR67 and AR204SZRA respectively).

\subsection{ED experiments}

Three set of sequential ED experiments were performed; the first step ran until the $\mathrm{pH}$ in the anolyte reached $1.5,1.7$ or 2 , whereas the second step ran equally for 3 days in each experiment. The time and final $\mathrm{pH}$ of the SSA suspension in each ED experiment are shown in Table 1. The $\mathrm{pH}$ values in the first step were similar to the results of previous ED experiments with the same ash [19], and the aim was to investigate their influence in the recovery of $\mathrm{P}$. The intensity was $50 \mathrm{~mA}$, chosen following the findings from previous researches using ED for P extraction from incinerated and gasification SSA [19, 20, 34, 46]. Voltage between the two electrodes was monitored during the whole experiment. The $\mathrm{pH}$ in both compartments and the conductivity of the ash suspension were measured twice a day during the ED experiments. The $\mathrm{pH}$ of the catholyte of the first step was adjusted to $<2$ with $\mathrm{HNO}_{3} 5 \mathrm{M}$, to avoid precipitations due to the production of $\mathrm{OH}-$ by the electrode reaction at the inert cathode.

At the end of each step, the ash suspension was filtered at atmospheric pressure, and after the first step the ash was flushed with $200 \mathrm{~mL}$ of DI water in order to displace the elements in solution retained in the humidified ash. The resulting liquid volume was measured, and the ash was dried during 48 hours at $50{ }^{\circ} \mathrm{C}$. The dried ash was loosened by hand in a mortar and stored in plastic bags under dry conditions. The electrodes were rinsed in $5 \mathrm{M} \mathrm{HNO}_{3}$, the membranes in $1 \mathrm{M} \mathrm{HNO}_{3}$, and 
190

191 through a $0.45 \mu \mathrm{m}$ syringe filter.

Table 1. Final pH in the SSA suspensions and duration of each step in the ED experiments.

\begin{tabular}{cccc}
\hline \multirow{2}{*}{ Experiment } & ED step & Final & Duration \\
& & $\mathrm{pH}$ & {$[$ hours $]$} \\
\hline A & $1^{\text {st }}$ & 1.5 & 125 \\
& $2^{\text {nd }}$ & 11.6 & 72 \\
\hline B & $1^{\text {st }}$ & 1.7 & 52.5 \\
& $2^{\text {nd }}$ & 12.2 & 72 \\
\hline C & $1^{\text {st }}$ & 2.0 & 27.5 \\
& $2^{\text {nd }}$ & 12.2 & 72 \\
\hline
\end{tabular}

193

194 Catholyte (in the first step) and anolyte (in the second step) samples were taken in $20 \mathrm{~mL}$ vials

195 before applying the electrical current and after 5 minutes of electrolyte circulation; at the end of the 196 experiments, catholyte and anolyte volumes were measured and sampled in $20 \mathrm{~mL}$ vials. $16 \mathrm{~mL}$ of 197 the samples from the catholyte in the $2^{\text {nd }}$ step was mixed with $4 \mathrm{~mL} \mathrm{HNO}_{3} 68 \%$, and heated at 200 $198 \mathrm{kPa}\left(120^{\circ} \mathrm{C}\right)$ for $30 \mathrm{~min}$. The element content was measured in the ICP-OES for all electrolytes after 199 filtration through a $0.45 \mu \mathrm{m}$ syringe filter. Na content in the catholyte of the second step was also 200 measured by ICP-OES.

202 The ED experiments were evaluated in terms of rates of P recovery and the impurity level of the obtained product. 
The amounts of $\mathrm{P}$ found in the anolyte of the $1^{\text {st }}$ and $2^{\text {nd }}$ steps were considered as recovered, since they were expected to be solutions rich in this element and depleted of impurities like metallic cations. The overall \% of P recovered was calculated as:

$$
\% P \text { recovery }=\frac{P \text { in anolytes }}{\text { Total } P \text { at the end of the experiment }}
$$

And the amount of $\mathrm{P}$ in the anolytes was calculated as:

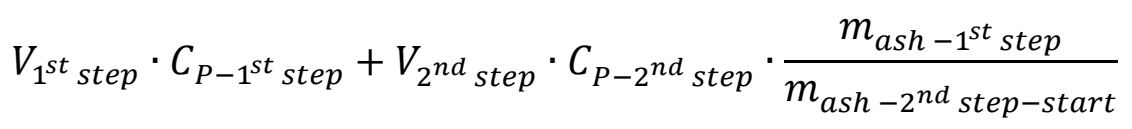

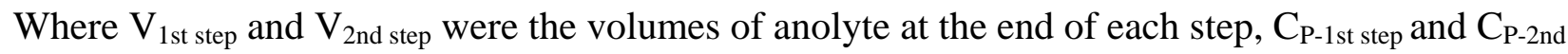
step the concentration of $\mathrm{P}$ in the anolytes for each ED step, whereas $\mathrm{m}_{\text {ash-1st step }}$ and $\mathrm{m}_{\text {ash-2nd step-start }}$ were the mass of dry ash at the end of the $1^{\text {st }}$ step and at the beginning of the $2^{\text {nd }}$ step, respectively.

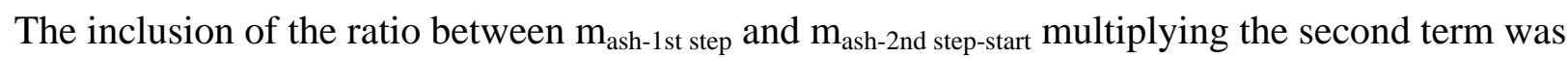
used to extrapolate the result of the $2^{\text {nd }}$ ED step to all the bulk dry ash mass after the $1^{\text {st }}$ step.

In order to assess the amount of impurities in the recovered $\mathrm{P}$, it was compared to wet process phosphoric acid (WPA), the product of leaching phosphate rock with sulfuric acid [47] which is applied to over $70 \%$ of mined phosphates [48]. A common parameter to evaluate the suitability of WPA in the fertilizer industry is the minor element ratios (MER), defined as:

$$
M E R=\frac{\mathrm{Fe}_{2} O_{3}+\mathrm{Al}_{2} O_{3}+\mathrm{MgO}}{\mathrm{P}_{2} O_{5}}
$$

Additionally, the amount of $\mathrm{P}$ bound to $\mathrm{Ca}$ and $\mathrm{Al} / \mathrm{Fe}(\mathrm{III})$ in the bulk SSA at the beginning and at the end of the $2^{\text {nd }}$ step were estimated by: 
- Considering all remaining $\mathrm{Ca}$ to be bound to $\mathrm{P}$ according to the stoichiometry of $\mathrm{Ca}_{3}\left(\mathrm{PO}_{4}\right)_{2}$. This implied an overestimation of these bindings, since there could be other Ca compounds not containing P, but it gave an overview of the effectiveness of the sequential ED method.

- Considering all $\mathrm{P}$ not bound to $\mathrm{Ca}$, in the previous point, to be bound to $\mathrm{Al}$ or $\mathrm{Fe}(\mathrm{III})$.

- In both cases, average concentrations of Ca and P in the bulk SSA were used. different experiments. 
Table 2. Element concentration (average \pm standard deviation) of untreated SSA from different batches analysed by ICP, after digestion following Danish Standard DS259 [44]. *Below ICP LOD

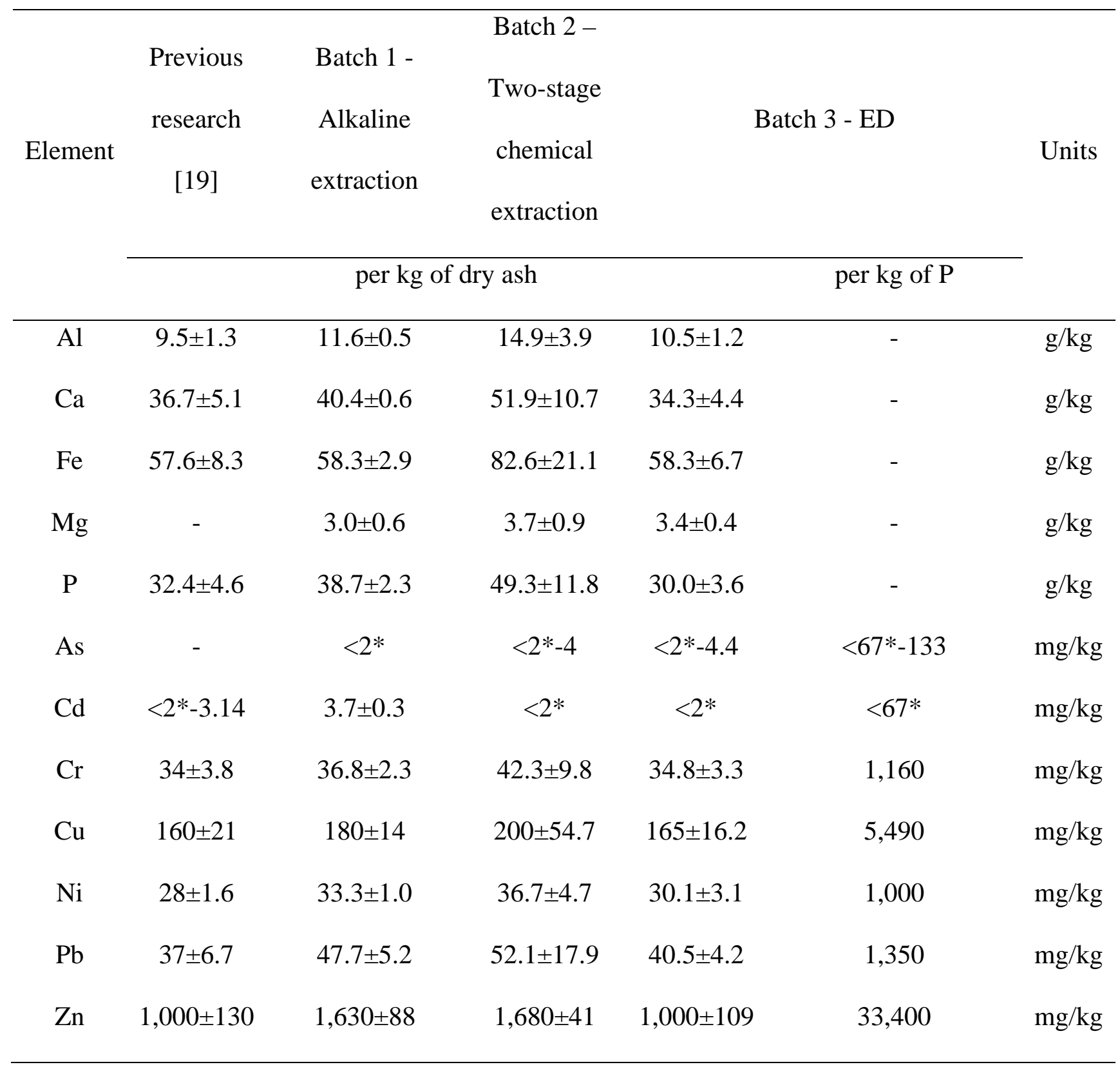

242 The solubility of all studied elements increased with the increase of $\mathrm{pH}$ except for Ca. Desorption of

$243 \mathrm{Fe}, \mathrm{Cr}, \mathrm{Cu}, \mathrm{Zn}$ was generally below $0.05 \%$, and the highest desorbed percentage of these being $0.5 \%$ 
for $\mathrm{Zn}$ at $\mathrm{pH}$ 13.3. The concentrations of $\mathrm{Cd}$ and $\mathrm{Pb}$ were below the limit of detection (LOD), 0.02 $\mathrm{mg} / \mathrm{L}$, in all alkaline leaching experiments. Solubilised percentages of As are not included due to the inhomogeneity of its concentration in the ashes, with some results below LOD (Table 2); however, the results show a high degree of solubilisation, equivalent to $0.6,1.6$ and $3.0 \mathrm{mg} / \mathrm{kg}$ of drySSA at $\mathrm{pH}$ 11.5, 13.0 and 13.3, respectively. Fig. 2 shows the results for $\mathrm{Al}, \mathrm{P}$ and $\mathrm{Ni}$, as the most remarkable results, as they are well above $5 \%$ in at least one of the alkaline extractions.

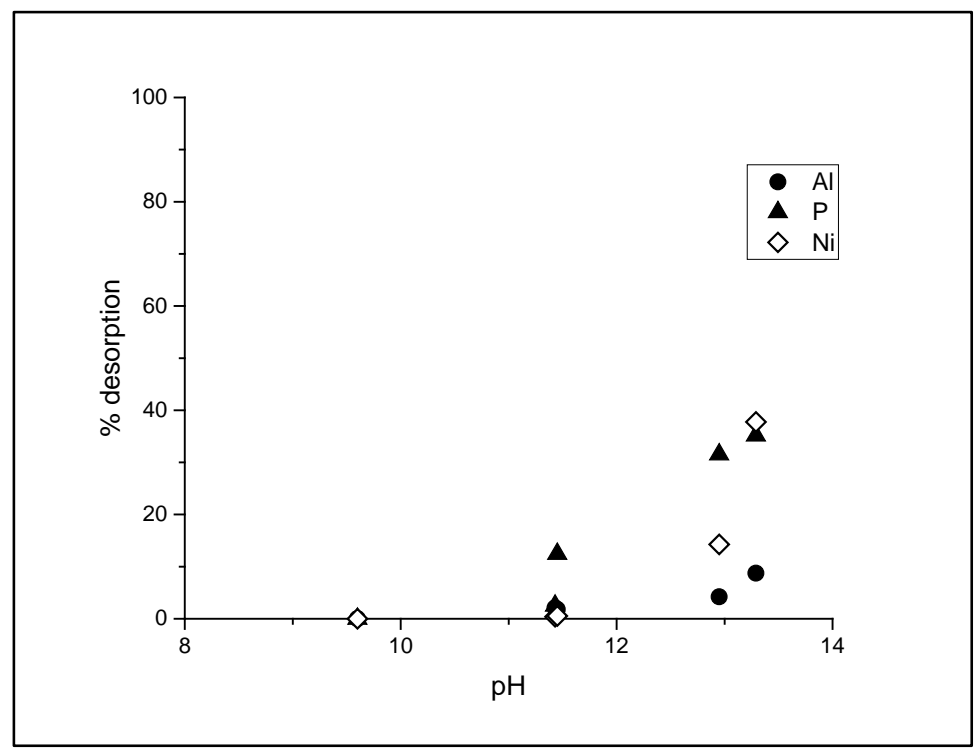

Fig. 2. Alkaline extraction of $\mathrm{Al}, \mathrm{Ni} \mathrm{P}$ in the SSA.

P solubilisation results in Fig. 2 confirms the existence of alkaline-soluble Fe(III)-P (and/or Al-P) bonds in these ashes, as previously suggested for the sameSSA [19]. P extraction using $1 \mathrm{M} \mathrm{NaOH}$ was $35 \%$, considerably lower than the result of using $1 \mathrm{M} \mathrm{HNO}_{3}$, which was $96 \%$ in the previous work with the same material [19]. This unsymmetrical leaching behaviour of an individual acid and alkaline extraction step was previously reported for chemically precipitated incineration SSA [36, 49]. There are mainly two explanations for this asymmetry. First, the presence of Ca-phosphates, which are acid-soluble but alkaline-insoluble; in contrast, Fe- or Al- phosphates are soluble at both 
highly acidic and alkaline conditions [35]. Second, P can simultaneously be adsorbed or reprecipitate in the presence of calcium compounds e.g. $\mathrm{CaCO}_{3}$ (these SSA contained $1.14 \pm 0.14 \%$ $\left.\mathrm{CaCO}_{3}\right), \mathrm{CaO}$ and $\mathrm{CaSO}_{4}$ at alkaline $\mathrm{pH}[37,38,41]$. As a consequence, it is not possible to determine accurately the predominance of each bond (Ca-, Fe(III)- and/or Al- phosphate). The reason for the low solubility of Fe in the alkaline extraction $\left(4.4 \cdot 10^{-5} \mathrm{M}\right.$ at $\left.\mathrm{pH} 13.0\right)$ is most likely due to re-precipitation of the solubilized Fe(III), previously bound to P, to hydroxides, for which the solubility are around $10^{-4} \mathrm{M}$ at $\mathrm{pH} 13$ [47].

An acidic step followed by an alkaline extraction allowed an extraction of up to 81\% of P (Table 3). This high percentage is possibly due to the removal of over $90 \%$ of $\mathrm{Ca}$ in the acidic step (Table 3), so that most Ca-P bindings are dissolved and $\mathrm{Al} / \mathrm{Fe}(\mathrm{III})-\mathrm{P}$ bindings (more soluble at $\mathrm{pH} 11-12$ than at $\mathrm{pH} 1.5$ [35]) are broken in the subsequent alkaline step without Ca compounds interference. In contrast, only 36\% of P was extracted following the opposite order (Table 3). Since most Ca was removed in the acidic step (Table 3), this poor result can be due to the formation of acid-soluble $\mathrm{Fe}(\mathrm{III})$ and/or $\mathrm{Al}$ solids in the alkaline step (i.e. hydroxides) and subsequent re-precipitation of $\mathrm{P}$ with $\mathrm{Al}$ and/or Fe(III) in the acidic step. Then, the ideal order for P recovery from these SSA is to use an acidic step followed by an alkaline step, as previously found for incineration SSA, where P has been precipitated with $\mathrm{Al}$ salts during the waste water treatment [36, 37]. In the alkaline step of this sequence, most $\mathrm{P}$ was extracted whereas all metals leached at low rate (Table $3,<1 \%$ for the rest), except for As leaching, which was equivalent to $2.2 \mathrm{mg} / \mathrm{kg}$ of dry SSA, representing at least a $50 \%$ of As content in Batch 3 (Table 2). Thus, this combination can also potentially separate P from most metals. Since results in Table 3 are obtained without running two or more replicates, they are used as an orientation and not for numerical comparisons in the next sections. 

extractions.

\begin{tabular}{ccccccc}
\hline & \multicolumn{3}{c}{ Alkaline-Acid extraction } & \multicolumn{3}{c}{ Acid-Alkaline extraction } \\
\cline { 2 - 6 } Element & Alkaline step & Acid step & Overall & Acid step & Alkaline step & Overall \\
& & & & & & \\
extraction & & & & \\
\hline $\mathrm{P}$ & $26 \%$ & $15 \%$ & $36 \%$ & $30 \%$ & $0 \%$ & $91 \%$ \\
$\mathrm{Ca}$ & $0 \%$ & $91 \%$ & $91 \%$ & $92 \%$ & $0 \%$ & $18 \%$ \\
$\mathrm{Al}$ & $6 \%$ & $16 \%$ & $21 \%$ & $17 \%$ & $0 \%$ & $17 \%$ \\
$\mathrm{Fe}$ & $0 \%$ & $1 \%$ & $1 \%$ & $16 \%$ & $0 \%$ & - \\
\hline \hline Final pH & 13.2 & 1.7 & - & 1.5 & 11.7 & \\
\hline
\end{tabular}

287 In a two-compartment ED cell, $\mathrm{pH}$ of the water and SSA suspension decreased when placed in the 288 anode compartment, or increased if placed in the cathode compartment due to water electrolysis at 289 the electrodes. Thus, an acid-alkaline sequential extraction can be adapted in an ED process 290 connecting a couple of 2-compartment ED cells (Fig. 1). 
293 The element distribution in the different compartments at the end of the experiments was 294 determined, considering that:

- The catholyte, the cathode and the cation exchange membrane were grouped as the cathode compartment in the $1^{\text {st }}$ step.

- The total mobilisation or desorption of each element, including P, was the sum of the masses found in all electrolyte solutions, membranes and electrodes at the end of the experiments.

- The amount of each element migrated to the catholyte in the $1^{\text {st }}$ step, and to the anolyte in the $2^{\text {nd }}$ step was defined as the difference in each element amount in the electrolyte solution at the end minus at the start of the step.

- The amounts of each element found at the anode in all ED experiments were always below $0.2 \%$ of the initial content in the untreated SSA. In consequence, their results are not sown in detail in the present work.

Mass balances for each element (except Cd and As), defined as the division of the amount found at the end of the experiments by the mass initially found in the initial SSA placed in the ED cell, were made to control the quality of each step of the experiments. Most mass balances varied between 80 and $120 \%$, which is probably due to the inherent inhomogeneity of the SSA (Table 2 and Section 3.1). Concentration measurements which were below the LOD used in the ICP analyses $(0.02$ $\mathrm{mg} / \mathrm{L}$ ), were considered to have this value, except for the anodes and the $1^{\text {st }}$ step catholyte prior to applying the electrical current which were considered to be zero. This arrangement affected several measurements in the cathode compartments for $\mathrm{Cr}, \mathrm{Cu}, \mathrm{Ni}$ and $\mathrm{Pb}$ and, together with $\mathrm{Cd}$, in the anolytes. The reason was to be able to calculate the mass balances and the worst-case value for other important parameters in the present work like the heavy metal to P ratio in the anolytes. The 
overall impact of these approximations was small: below 2.5\% of the total final element mass found at the end of the ED experiments.

\subsubsection{Evolution of ED cell voltage, ash suspension $\mathrm{pH}$ and conductivity}

The voltage between the two electrodes decreased during both steps of the three sets of ED experiments, which corresponded to an increase in electrical conductivity, as well as the $\mathrm{pH}$ decrease ( $1^{\text {st }}$ step) or increase $\left(2^{\text {nd }}\right.$ step) of the SSA suspension. This is due to the increase of ionic concentration in all electrolyte solutions by the generation of either protons ( $1^{\text {st }}$ step) or hydroxides ( $2^{\text {nd }}$ step) at the electrodes, as well as the desorption of the elements from the SSA with the changes in $\mathrm{pH}$. Moreover, the rise in conductivity discards possible fouling in the ion exchange membranes [50]. The final $\mathrm{pH}$ values of each step are seen in Table 1.

\subsubsection{P-recovery: $1^{\text {st }}$ and $2^{\text {nd }}$ step}

Fig. 3 shows the distribution of $\mathrm{P}$ at the end of the sequential ED experiments. The amount of $\mathrm{P}$ in the $1^{\text {st }}$ step anolyte increased with the time of remediation: 126, 239 and $294 \mathrm{mg}$ P (Fig. 3) after 27.5, 52.5 and 125 hours (Table 1). This is consistent with the previous results with the same SSA [19], where the recovered amounts are calculated to be 147, 261 and $295 \mathrm{mg}$ of P after 24, 72 and 168 hours, respectively. Therefore, no big differences were observed above 72 hours of ED experiments in terms of $\mathrm{P}$ recovery (below 15\%), despite the much longer treatment. This can be explained by the low solubility of Fe(III)-phosphates at acidic $\mathrm{pH}$ [35], and the higher $\mathrm{P}$ migration towards the cathode with longer treatments (Fig. 3, and [19]), due to the formation of positively charged Fe-P and Al-P complexes. Therefore, a higher recovery cannot be expected with a longer duration of a single ED stage using the configuration of the $1^{\text {st }}$ step. 


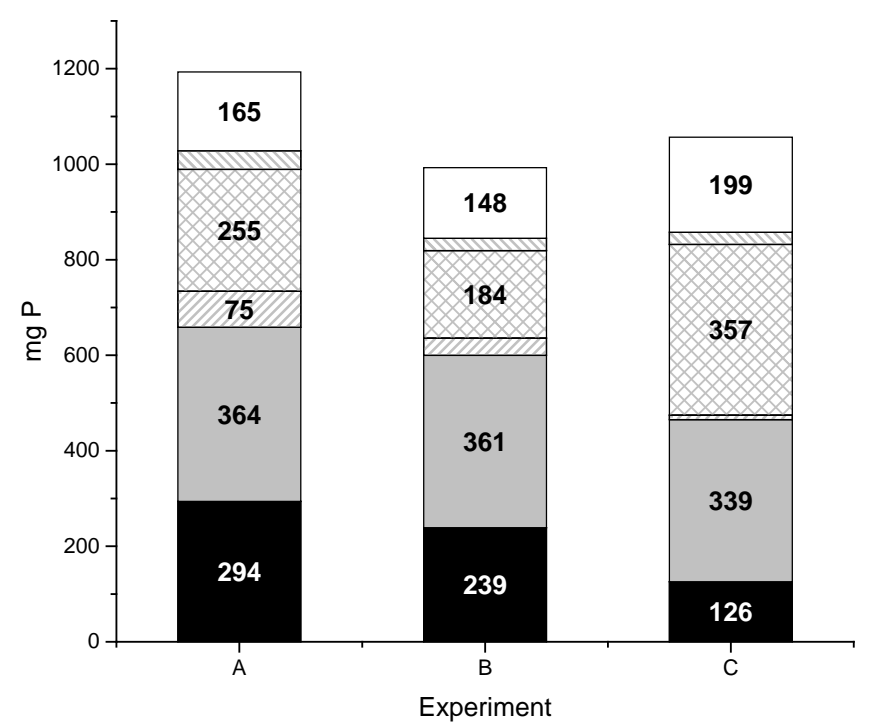

Anolyte 1st step $\quad \square$ Anolyte 2nd step (increase) Cathode compartment 1st step Cathode compartment 2nd step+AEM

Fig. 3. P distribution at the end of ED experiments.

339 Around 6-8 grams of the bulk SSA resulting from the first step were not treated in the second step, 340 because a part of it ( 3 grams) was used for sampling and the rest could not be recovered from the 341 filter paper. The corresponding amounts of $\mathrm{P}$ are shown in Fig. 3 as "Bulk ash not treated in the $2^{\text {nd }}$ 342 step”. Despite that, a higher amount of $\mathrm{P}$ was recovered to the anolyte in the $2^{\text {nd }}$ step compared to 343 the $1^{\text {st }}$ step for all three experiments (Fig. 3), which is consistent with the results of the second step 344 of the acid-alkaline extraction (Table 3).

345 As seen, a lower $\mathrm{pH}$ in the first step (Table 1) implied a higher recovery of P mass in the anolytes 346 (Fig. 3). The amounts of P recovered in the $2^{\text {nd }}$ step (Fig. 3) were similar ( $350 \mathrm{mg}$ ) for the three 347 experiments, and below the estimated amount of $\mathrm{P}$ bound to $\mathrm{Fe}(\mathrm{III}) / \mathrm{Al}$ in the bulk SSA at the beginning of this step (Table 4). In fact, Fe(III)- or Al-P bindings would still be predominant in the 
bulk ash at the end of experiments A and B (Table 4). Considering a valence of three, $350 \mathrm{mg}$ of $\mathrm{P}$ represent a transport number of around 0.25 in the $2^{\text {nd }}$ step. A reason for this low migration can be a low solubilisation in the cathode compartment, as a higher amount of $\mathrm{P}$ was bound to $\mathrm{Fe}(\mathrm{III})$ or $\mathrm{Al}$ in the ashes (Table 4) than found in the cathode compartment at the end of the $2^{\text {nd }}$ step (Fig. 3). In order to increase P mobilisation from these SSA, longer remediation times or higher initial $\mathrm{NaOH}$ concentrations could be used, although it requires further study.

Table 4. Estimation of mg of average $\mathrm{P}$ bound to $\mathrm{Ca}$ or $\mathrm{Al} / \mathrm{Fe}(\mathrm{III})$ in the bulk SSA at the end of the $1^{\text {st }}$ and the $2^{\text {nd }}$ ED step.

\begin{tabular}{ccccccc}
\hline \multirow{2}{*}{ mg P bound to } & \multicolumn{7}{c}{ At the end of the $1^{\text {st }}$ step } & \multicolumn{4}{c}{ At the end of the 2nd step } \\
\cline { 2 - 7 } & A & B & C & A & B & C \\
\hline Ca & 78 & 119 & 197 & 74 & 84 & 213 \\
Al/Fe(III) & 658 & 468 & 436 & 180 & 99 & 144 \\
\hline
\end{tabular}

The total mass of P recovered in experiment B was $600 \mathrm{mg}$ (Fig. 3), with a total remediation time of $124.5 \mathrm{~h}$. This amount doubled the results of running only the $1^{\text {st }}$ ED step for 125 ( $1^{\text {st }}$ step of experiment A) and 168 hours (see the beginning of this section), even though not all bulk SSA was used in the $2^{\text {nd }}$ step, and confirms its potential to treat these SSA. P-recoveries in experiments A, B and $\mathrm{C}$ were 62, 70 and 54\%, respectively. The reason for the lower \% P-recovery in experiment A than $\mathrm{B}$, despite a higher amount of $\mathrm{P}$ recovered, is primarily due to the higher content of $\mathrm{P}$ in the initial ash (Fig. 3). 
368 The P concentrations in the anolyte after the $2^{\text {nd }}$ step were $1.7,1.3$ and $1.0 \mathrm{~g} / \mathrm{L}$ for $\mathrm{A}$, B and C 369 respectively (Table 5), higher than the results previously achieved with a single ED step of the 370 sameSSA (0.5-0.9 g P/L [19]). Nevertheless, these values are far below concentrations of 371 commercial phosphoric acid or liquid fertilisers (around 450 g P/L [19]) or WPA (above 340 g P/L 372 [47]), which needs to be addressed in future studies. For the three experiments, MER were lower in 373 the anolyte after the $2^{\text {nd }}$ than after the $1^{\text {st }}$ step (Table 5): 0.05, 0.04 and 0.04 at the end of 374 experiments A, B and C respectively. These values were below the limit for WPA (0.085) to be 375 used in the production of diammonium phosphate (DAP [47]), the most commonly traded fertilizer 376 in the world according to the International Fertilizer Industry Association. Moreover, individual Al, 377 Fe and Mg ratios to P were below or in the range of WPA values for all experiments, except for $378 \quad \mathrm{Fe} / \mathrm{P}$ in experiment A (Table 5). 
Table 5. Chemical composition of the anolyte solutions in each step of the ED experiments. MER

381 values exceeding 0.085 , and metal to P ratios exceeding the values in WPA [47] are shown in bold.

* below LOD in ICP-OES.

Experiment

\begin{tabular}{|c|c|c|c|c|c|c|c|c|}
\hline \multirow{3}{*}{ Parameter } & \multicolumn{6}{|c|}{ Experiment } & \multirow{3}{*}{ WPA [47] } & \multirow{3}{*}{ Units } \\
\hline & \multicolumn{2}{|c|}{$\mathrm{A}$} & \multicolumn{2}{|c|}{ B } & \multicolumn{2}{|c|}{$\mathrm{C}$} & & \\
\hline & $1^{\text {st }}$ step & $2^{\text {nd }}$ step & $1^{\text {st }}$ step & $2^{\text {nd }}$ step & $1^{\text {st }}$ step & $2^{\text {nd }}$ step & & \\
\hline P content & 0.03 & 0.02 & 0.50 & 1.32 & 0.25 & 1.01 & $\sim 340-450$ & g P/L \\
\hline $\mathrm{Al} / \mathrm{P}$ & 0.15 & 0.05 & 0.02 & 0.02 & 0.02 & 0.03 & $<0.03$ & \\
\hline $\mathrm{Fe} / \mathrm{P}$ & 0.02 & 0.01 & 0.06 & 0.02 & 0.02 & 0.01 & $<0.04$ & $\mathrm{~kg} / \mathrm{kg} \mathrm{P}$ \\
\hline $\mathrm{Mg} / \mathrm{P}$ & 0.07 & 0.04 & 0.02 & 0.01 & 0.05 & 0.01 & $0.01-0.03$ & \\
\hline MER & 0.13 & 0.05 & 0.06 & 0.04 & 0.07 & 0.04 & - & - \\
\hline $\mathrm{As} / \mathrm{P}$ & 94 & 108 & $<40^{*}$ & 139 & 159 & 117 & $20-70$ & \\
\hline $\mathrm{Cd} / \mathrm{P}$ & $<31^{*}$ & $<11^{*}$ & $<40^{*}$ & $<15^{*}$ & $<80^{*}$ & $<20 *$ & $120-500$ & \\
\hline $\mathrm{Cr} / \mathrm{P}$ & $<31^{*}$ & 14 & $<40^{*}$ & $<15^{*}$ & $<80^{*}$ & $<20 *$ & $100-3,000$ & \\
\hline $\mathrm{Cu} / \mathrm{P}$ & 683 & 250 & 491 & 150 & 627 & 42 & $10-400$ & $\mathrm{mg} / \mathrm{kg} \mathrm{P}$ \\
\hline $\mathrm{Ni} / \mathrm{P}$ & 64 & 22 & $<40^{*}$ & $<15^{*}$ & 93 & 21 & $100-700$ & \\
\hline $\mathrm{Pb} / \mathrm{P}$ & $<31^{*}$ & $<11^{*}$ & $<40^{*}$ & 48 & $<80^{*}$ & $<20^{*}$ & $<4$ & \\
\hline $\mathrm{Zn} / \mathrm{P}$ & 2,200 & 746 & 1,970 & 834 & 4,270 & 1,070 & $100-10,000$ & \\
\hline
\end{tabular}

384 Similarly to the acid-alkaline extraction (section 3.2), the high $\mathrm{pH}$ in the $2^{\text {nd }}$ step enabled an

385 effective separation of $\mathrm{P}$ and most heavy metals .As it can be seen in Table 5, the heavy metal to P

386 ratio in the anolyte at the end of each experiment decreased in comparison to the anolyte in the $1^{\text {st }}$

387 step for some of the elements: $\mathrm{Cu}, \mathrm{Zn}$ in all experiments, $\mathrm{Ni}$ in experiments $\mathrm{A}$ and $\mathrm{C}$, $\mathrm{Cr}$ in 
experiment $\mathrm{A}$ and $\mathrm{As}$ in experiment $\mathrm{C}$; $\mathrm{As} / \mathrm{P}$ increased in experiments $\mathrm{A}$ and $\mathrm{B}$, whereas $\mathrm{Pb} / \mathrm{P}$ increased in experiment $\mathrm{B}$. The rest of heavy metals concentrations were below LOD after the $2^{\text {nd }}$ step, and therefore it cannot be concluded if they were decreased or increased in relation to the $1^{\text {st }}$ step. The values eventually achieved in all experiments for $\mathrm{Cr}, \mathrm{Cu}, \mathrm{Ni}, \mathrm{Pb}$ and $\mathrm{Zn}$ were at least an order of magnitude below the initialSSA (calculated from Table 2) and, except for $\mathrm{Pb}$ (which were below LOD), in the range or below the values found in WPA [47]. The arsenic ratio in the solutions was in the range 108-139 mg As/kg P, similar to the highest value in the range of the untreated SSA (133 mg As/kg P, calculated from Table 2). This can be explained by its similar ionic form to $\mathrm{PO}_{4}{ }^{3-}$ once extracted from the bulk SSA in the $2^{\text {nd }}$ ED step: MINTEQ calculations with the concentrations and $\mathrm{pH}$ of the catholyte at the end of each $2^{\text {nd }}$ step indicate a high predominance of arsenate $\left(\mathrm{AsO}_{4}{ }^{3-}\right.$ ). This must be taken into account in future research addressing ED recovery of P from SSA with higher concentration in As.

\section{Conclusions}

In the present work, up to $70 \%$ of $\mathrm{P}$ was recovered from low-temperature gasification SSA using an innovative ED sequential process. The SSA had a high proportion of Fe(III)-P bindings . The result is a considerable improvement for extraction of $\mathrm{P}$ from these SSA compared to treatment in a single 2-compartment ED cell, where the recovery was less than 30\%.

Phosphorus was effectively separated from $\mathrm{Al}, \mathrm{Ca}, \mathrm{Fe}, \mathrm{Mg}$ and most heavy metals. This was partially due to the alkaline $\mathrm{pH}$ of the ash suspension in one of the steps of the ED treatment, where $\mathrm{P}$ bound to $\mathrm{Fe}(\mathrm{III})$ and/or $\mathrm{Al}$ was extracted and most metals were insoluble. The final product was an acidic P-solution with a metal content comparable to WPA, and a combined impurity level of Al, Fe and Mg suitable for the manufacturing of DAP, the most commonly trade mineral fertilizer. 
Future studies need to investigate different alternatives to remove arsenic as well as to increase the concentration in the final P-product.

\section{Acknowledgements}

The Energy Technology Development and Demonstration Program, Danish Ministry of Climate, Energy and Buildings is acknowledged for funding this research as part of the project "Fuel Flexible, Efficient and Sustainable Low Temperature Biomass Gasification".

\section{References}

[1] K. C. van Dijk, J. P. Lesschen, and O. Oenema, "Phosphorus flows and balances of the European Union Member States,", Science of the Total Environment, vol. 542, pp. 10781093, 2016.

[2] D. Cordell, J. O. Drangert, and S. White, "The story of phosphorus: Global food security and food for thought," Global Environmental Change-Human and Policy Dimensions, Review vol. 19, no. 2, pp. 292-305, May 2009.

[3] C. J. Dawson and J. Hilton, "Fertiliser availability in a resource-limited world: Production and recycling of nitrogen and phosphorus," Food Policy, Article vol. 36, pp. S14-S22, Jan 2011.

[4] M. B. McBride and G. Spiers, "Trace element content of selected fertilizers and dairy manures as determined by ICP-MS," Communications in Soil Science and Plant Analysis, Article vol. 32, no. 1-2, pp. 139-156, 2001. 
[5] M. D. Taylor, "Accumulation of uranium in soils from impurities in phosphate fertilisers," LANDBAUFORSCHUNG VOLKENRODE, vol. 57, no. 2, pp. 133-139, 2007.

[6] C. Sartorius, J. von Horn, and F. Tettenborn, "Phosphorus Recovery from WastewaterExpert Survey on Present Use and Future Potential," Water Environment Research, Article vol. 84, no. 4, pp. 313-322, Apr 2012.

[7] K. Gorazda, Z. Wzorek, B. Tarko, A. K. Nowak, J. Kulczycka, and A. Henclik, "Phosphorus cycle - possibilities for its rebuilding," Acta Biochimica Polonica, vol. 60, no. 4, pp. 725730, 2013.

[8] O. F. Schoumans, F. Bouraoui, C. Kabbe, O. Oenema, and K. C. van Dijk, "Phosphorus management in Europe in a changing world," Ambio, Article vol. 44, pp. S180-S192, Mar 2015.

[9] H. Herzel, "Technical comparison on the design, operation and performances of ash processes - Deliverable D 4.1 of the P-REX project," BAM, 2015.

[10] "Denmark without waste," The Danish Government, 2013.

[11] P. J. A. Withers et al., "Stewardship to tackle global phosphorus inefficiency: The case of Europe," Ambio, Article vol. 44, pp. S193-S206, Mar 2015.

[12] E. Paul, M. L. Laval, and M. Sperandio, "Excess sludge production and costs due to phosphorus removal," ENVIRONMENTAL TECHNOLOGY, vol. 22, no. 11, pp. 1363-1371, 2001.

[13] S. Donatello, D. Tong, and C. R. Cheeseman, "Production of technical grade phosphoric acid from incinerator sewage sludge ash (ISSA)," Waste Management, Article vol. 30, no. 89, pp. 1634-1642, Aug-Sep 2010. 
[14] G. Rodriguez-Garcia, M. Molinos-Senante, A. Hospido, F. Hernandez-Sancho, M. T. Moreira, and G. Feijoo, "Environmental and economic profile of six typologies of wastewater treatment plants," WATER RESEARCH, vol. 45, no. 18, pp. 5997-6010, 2011.

[15] O. Kruger, A. Grabner, and C. Adam, "Complete Survey of German Sewage Sludge Ash," Environmental Science \& Technology, Article vol. 48, no. 20, pp. 11811-11818, Oct 2014.

[16] S. Donatello and C. R. Cheeseman, "Recycling and recovery routes for incinerated sewage sludge ash (ISSA): A review," Waste Management, Review vol. 33, no. 11, pp. 2328-2340, Nov 2013.

[17] T. P. Thomsen, G. Ravenni, J. K. Holm, J. Ahrenfeldt, H. Hauggaard-Nielsen, and U. B. Henriksen, "Screening of various low-grade biomass materials for low temperature gasification: Method development and application," Biomass and Bioenergy, vol. 79, pp. 128-144, 8// 2015.

[18] M. Franz, "Phosphate fertilizer from sewage sludge ash (SSA)," Waste Management, Article vol. 28, no. 10, pp. 1809-1818, 2008.

[19] R. Parés Viader, P. E. Jensen, L. M. Ottosen, J. Ahrenfeldt, and H. Hauggaard-Nielsen, "Electrodialytic extraction of phosphorus from ash of low-temperature gasification of sewage sludge," Electrochimica Acta, vol. 181, pp. 100-108, 2015.

[20] B. Ebbers, L. M. Ottosen, and P. E. Jensen, "Comparison of two different electrodialytic cells for separation of phosphorus and heavy metals from sewage sludge ash," Chemosphere, 2015.

[21] C. Dittrich, W. Rath, D. Montag, and J. Pinnekamp, "Phosphorus recovery from sewage sludge ash by a wet-chemical process," presented at the International Conference on Nutrient Recovery from Wastewater Streams, 2009. 
[22] J. Lehmkuhl and M. Lebek, "Purifying crude phosphoric acid, comprises reacting crude phosphoric acid with ash, calcium hydroxide and at least one sulfide, and depositing the acid-insoluble portion of the solids to obtain a filtrate or eluate," Patent DE102014006278B3; WO2015165481-A1.

[23] M. Takhim, "Method for recovering ash from waste incineration used in e.g. agricultural field, involves digesting ash by leaching liquor containing phosphate ions and separating liquid phase comprising phosphate ions from solid phase," Patent WO2015091946-A1.

[24] J. Lehmkuhl and M. Lebek, "Extracting precipitates of calcium nitrate, calcium phosphate, calcium sulfate or aluminum hydroxophosphate from phosphate-containing ash from waste incineration plants, comprises extracting e.g. calcium phosphate and calcium nitrate," Patent DE102013018650-B3; WO2015067328-A1.

[25] J. Lehmkuhl and M. Lebek, "Recovering precipitates including e.g. calcium nitrate from phosphate-containing solids, comprises e.g. reacting solids with e.g. nitric acid or phosphoric acid, and adding calcium oxide or calcium carbonate to filtrate or supernatant," Patent DE102013018652-A1.

[26] A. Schönberg, K. Samiei, H. Kern, and H. Raupenstrauch, "Der RecoPhos-Prozess Rückgewinnung von Phosphor aus KIärschlammasche, The recophos process: recovering phosphorus from sewage,", Osterreichische Wasser- Und Abfallwirtschaft, vol. 66, no. 1112, pp. 403-407, 2014.

[27] C. Adam, B. Peplinski, M. Michaelis, G. Kley, and F. G. Simon, "Thermochemical treatment of sewage sludge ashes for phosphorus recovery," Waste Management, Article vol. 29, no. 3, pp. 1122-1128, Mar 2009. 
[28] O. Krüger, C. Adam, L. Hermann, and H. Herzel, "Sewage sludge ash - A promising secondary phosphorus source for fertilizer production," Science of the Total Environment, vol. 542, pp. 1136-1143, 2016.

[29] J. Stemann, C. Adam, and B. Peplinski, "Thermochemical treatment of sewage sludge ash with sodium salt additives for phosphorus fertilizer production - Analysis of underlying chemical reactions," Waste Management, vol. 45, 2015.

[30] Y. Cohen, "Phosphorus dissolution from ash of incinerated sewage sludge and animal carcasses using sulphuric acid," Environmental Technology, Article vol. 30, no. 11, pp. 1215-1226, 2009.

[31] K. Gorazda, Z. Kowalski, and Z. Wzorek, "From sewage sludge ash to calcium phosphate fertilizers," Polish Journal of Chemical Technology, Article vol. 14, no. 3, pp. 54-58, 2012.

[32] A. Sano, M. Kanomata, H. Inoue, N. Sugiura, K.-Q. Xu, and Y. Inamori, "Extraction of raw sewage sludge containing iron phosphate for phosphorus recovery," Chemosphere, vol. 89, no. 10, pp. 1243-1247, 2012.

[33] P. Wilfert, P. S. Kumar, L. Korving, G.-J. Witkamp, and M. C. M. van Loosdrecht, "The Relevance of Phosphorus and Iron Chemistry to the Recovery of Phosphorus from Wastewater: A Review," Environmental Science and Technology, vol. 49, no. 16, pp. 94009414, 2015.

[34] L. M. Ottosen, P. E. Jensen, and G. M. Kirkelund, "Electrodialytic Separation of Phosphorus and Heavy Metals from Two Types of Sewage Sludge Ash," Separation Science and Technology, vol. 49, no. 12, pp. 1910-1920, 2014.

[35] W. Stumm and J. J. Morgan, Aquatic chemistry : Chemical equilibria and rates in natural waters. Wiley, 1996. 
[36] S. Petzet, B. Peplinski, and P. Cornel, "On wet chemical phosphorus recovery from sewage sludge ash by acidic or alkaline leaching and an optimized combination of both," Water Research, Article vol. 46, no. 12, pp. 3769-3780, Aug 2012.

[37] S. Petzet, B. Peplinski, S. Y. Bodkhe, and P. Cornel, "Recovery of phosphorus and aluminium from sewage sludge ash by a new wet chemical elution process (SESAL-Phosrecovery process)," Water Science and Technology, Article vol. 64, no. 3, pp. 693-699, 2011.

[38] P. Benzing and C. J. Rickardson, "CaCO3 causes underestimation of NaOH extractable phosphorus in sequential fractionations," Soil Science, Article vol. 170, no. 10, pp. 802-809, Oct 2005.

[39] D. C. Ribeiro, G. Martins, R. Nogueira, J. V. Cruz, and A. G. Brito, "Phosphorus fractionation in volcanic lake sediments (Azores, Portugal)," Chemosphere, Chemosphere, Chemosphere, vol. 70, no. 7, pp. 1256-1263, 2008.

[40] Y. Kalmykova and K. K. Fedje, "Phosphorus recovery from municipal solid waste incineration fly ash," Waste Management, vol. 33, no. 6, pp. 1403-1410, 2013.

[41] J. Chen, H. Kong, D. Wu, X. Chen, D. Zhang, and Z. Sun, "Phosphate immobilization from aqueous solution by fly ashes in relation to their composition," Journal of Hazardous Materials, vol. 139, no. 2, pp. 293-300, 2007.

[42] D. Touaibia, H. Kerdjoudj, and A. T. Cherif, "Concentration and purification of wet industrial phosphoric acid by electro-electrodialysis," JOURNAL OF APPLIED ELECTROCHEMISTRY, vol. 26, no. 10, pp. 1071-1073, 1996.

[43] J. Ahrenfeldt, T. Thomsen, U. B. Henriksen, and L. R. Clausen, "Biomass gasification cogeneration - A review of state of the art technology and near future perspectives," Applied Thermal Engineering, vol. 50, no. 2, pp. 1407-1417, 2013. 
[44] P. Rothenhofer, A. Huber, B. Kainzmaier, S. Wohnlich, and S. Peiffer, "Ein Vergleich von vier Methoden zur Bestimmung des Karbonatgehaltes, A comparison of four methods for determining carbonate contents," (in German), Wasser Und Boden, Wasser Boden, Wasser Und Boden Zeitschrift Fuer Die Gesamte Wasserwirtschaft, vol. 52, no. 10, pp. 37-42, 2000.

[45] Danish standard, "DS259: Determination of metals in water, sludge and sediments - General guidelines for determination by atomic absorption spectrophotometry in flame," 2003.

[46] P. Guedes, N. Couto, L. M. Ottosen, and A. B. Ribeiro, "Phosphorus recovery from sewage sludge ash through an electrodialytic process," WASTE MANAGEMENT, vol. 34, no. 5, pp. 886-892, 2014.

[47] R. Gilmour, "Phosphoric Acid Purification, Uses, Technology, and Economics," CRC Press (Taylor \& Francis Group), 2014.

[48] Scholz, R. W., Roy, A. H., \& Hellums, D. T. Sustainable Phosphorus Management: $a$ Global Transdisciplinary Roadmap," Springer, 2014.

[49] B. K. Biswas, K. Inoue, H. Harada, K. Ohto, and H. Kawakita, "Leaching of phosphorus from incinerated sewage sludge ash by means of acid extraction followed by adsorption on orange waste gel," Journal of Environmental Sciences, vol. 21, no. 12, pp. 1753-1760, // 2009.

[50] M. Araya-Farias and L. Bazinet, "Effect of calcium and carbonate concentrations on anionic membrane fouling during electrodialysis," Journal of Colloid and Interface Science, vol. 296, no. 1, pp. 242-247, 2006. 